\title{
Record Number of Papers Submitted for 1988 MRS Fall Meeting
}

Over 2,000 papers have been submitted to the Materials Research Society for presentation at its 1988 Fall Meeting to be held in Boston, November 28 - December 3. This is an increase of $15 \%$ over the papers presented at the 1987 Fall Meeting. "We are delighted with the enthusiastic response to the Call for Papers for this meeting," said Slade Cargill, one of the 1988 Fall Meeting chairs. In addition to an increase in oral paper presentations at the meeting, the traditional Tuesday and Thursday evening poster sessions have also been expanded to include a third session Wednesday evening featuring 180 papers.

"The diversity of the topical symposia will offer a thorough examination of mainstream topics as well as introduce some new ones," said Cargill. New topics for the Fall Meeting include Chemical Perspectives of Microelectronic Materials (Symposium E), Liquid Crystal Polymers (Symposium I), New Materials Approaches to Tribology: Theory and Applications (Symposium S), Atomic Scale Calculations in Materials Science (Symposium T), and Nondestructive Monitoring of Materials Properties (Symposium U).

According to Cargill, high temperature superconductivity will continue to draw attention from participants through its large number of topical papers.

\section{Telephone/Fax Registrations Now Accepted}

In addition to mail-in registrations, both meeting and short course registrations will be accepted by telephone or fax this year for the convenience of MRS meeting attendees. To register by telephone, simply call MRS at (412) 367-3003 and ask for the Meeting Registration Desk. Fax copies of registration forms should be sent to MRS at (412) 367-4373. Complete registration details and forms are in the Preliminary Program, which is mailed to all MRS members. If you need a Preliminary Program or additional registration forms for the 1988 Fall Meeting, contact:

Materials Research Society

9800 McKnight Road, Suite 327

Pittsburgh, PA 15237

Telephone (412) 367-3003

Fax (412) 367-4373

A record number of attendees is expected at the Boston Meeting, and early registration is recommended for both the meeting and the short courses. Class sizes will be limited for the 22 selected short courses to be presented in conjunction with the meeting. The Fall Meeting short courses are listed elsewhere in this issue, and the symposia are listed below.
Meeting Chairs

G. Slade Cargill

IBM T.J. Watson Research Center

P.O. Box 218

Yorktown Heights, NY 10598

(914) 945-1958

D. Wayne Goodman

Department of Chemistry

Texas A \& M University

College Station, TX 77843

(409) 845-0214

J. Francis Young

University of Illinois

202A Ceramics Building

105 S. Goodwin

Urbana, IL 61801

(217) 244-6210

\section{MRS Fall Meeting Symposia}

A- Processing and Characterization of Materials Using Ion Beams

B- Laser and Particle-Beam Chemical Processes on Surfaces

C- Thin Films: Stresses and Mechanical Properties

D- Advanced Methods for Characterizing the Surfaces/Interfaces of Materials

E- Chemical Perspectives of Microelectronic Materials

F- Preparation and Materials Properties of High Temperature Superconductors

G- Multicomponent Ultrafine Microstructures
H- High Temperature Ordered Intermetallic Alloys

I- Liquid Crystal Polymers

J- The Materials Science and Engineering of Rigid-Rod Polymers

$\mathrm{K}-$ Materials Science of Mineralized Biological Tissues

L- Graphite Intercalation Compounds: Science and Applications

M-Solid State Ionics

N- Fractal Aspects of Materials: Disordered Systems

O- Fly Ash and Coal Conversion ByProducts: Characterization, Utilization and Disposal V

P- Pore Structure and Permeability of Cementitious Materials

Q- Characterization of Structure and Chemistry of Defects in Materials

R- High Resolution Microscopy of Materials

S- New Materials Approaches to Tribology: Theory and Applications

T- Atomic Scale Calculations in Materials Science

U- Nondestuctive Monitoring of Materials Properties

V- Synchrotron Radiation in Materials Research

W- Advances in Materials, Processing and Devices in III-V Compound Semiconductors

$X$ - Frontiers of Materials Research

Y - Selected Topics in Electronic Materials

\section{For 1988 MRS Fall Meeting and Short Course Attendees}

\section{Special Room Rates}

\section{Available Until October 28, 1988}

At the Boston Marriott/Copley Place And the Westin Hotel/Copley Place

Take advantage of these special room rates by making your reservation with either hotel by October 28, 1988.

Boston Marriott/Copley Place

(800) 228-9290

Westin Hotel/Copley Place

(617) $236-5800$

(800) 228-3000

(617) $262-9600$

\section{Discount Air Fares}

Available November 25 through December 10, 1988

\section{Delta Air Lines is offering:}

Additional 5\% off Delta's publicized roundtrip fares to Boston from within the U.S. and San Juan.

$40 \%$ off Delta's unrestricted roundtrip coach fares to Boston (35\% off from Canadian cities). Seven-day advance reservations required.

Other restrictions may apply.

Call Delta at (800) 241-6760 and refer to File Number HO 238. 


\section{November 27-December 3, 1988}

\section{Boston Marriott/Copley Place}

Short Courses offered in conjunction with the Materials Research Society's 1988 Fall Meeting and Equipment Exhibit will cover the latest developments in materials science and technology. SPECIALTY, REVIEW, and SURVEY courses complement the symposia topics and are designed to meet the ongoing needs of professional scientists, engineers, technical staff, and managers for knowledge about forefront techniques in materials characterization and fabrication. CLASS SIZES ARE LIMITED: Early telephone registrations are encouraged.

Title

\section{ADVANCED MATERIALS}

M-04 Optoelectronic Materials, Processes, and Devices

Instructor: Mool C. Gupta

Friday-Saturday, Dec. 2-3

M-05 Fabrication, Characterization, and Applications of High-

Temperature Superconducting Materials

Instructors: Robert E. Schwall \& Terry P. Orlando

Sunday-Monday, Nov. 27-28

Tuition

M-06 Growth and Characterization of Diamond and Diamond Films Instructors: Daniel L. Flamm, Thomas R. Anthony \& Jeffrey T. Glass Thursday, Dec. 1

M-07 Polymers for Electronic and Photonic Applications

Instructors: C.P. Wong, Donald C. Hofer, Gary N. Taylor \& Gerald R.

Meredith

Friday-Saturday, Dec. 2-3

M-08 Nature of Solid Lubricants and their Applications

Instructors: Harold E. Sliney

Monday, Nov. 28

$\$ 485$

\section{CHARACTERIZATION OF MATERIALS}

C-01 Modern Materials Analysis Techniques

Instructors: James A. Borders, Kenneth H. Eckelmeyer \&

Suzanne H. Weissman

Monday-Wednesday, Nov. 28-30

-02 Electron Microscopy of Thin Films

Instructors: Alton D. Romig, Jr. \& David B. Williams

Thursday-Friday, Dec. 1-2

C-03 Surface and Thin Film Analysis

Instructors: Leonard C. Feldman \& James W. Mayer

Friday-Saturday, Dec. 2-3

C-06 Characterization of Semiconductors using Deep Level Transient Spectroscopy

Instructor: Charles E. Barnes

Tuesday, Nov. 29

C-09 Fractals: Concepts and Applications in Materials Science and Engineering

Instructors: James E. Martin \& Alan J. Hurd

Sunday-Monday, Nov. 27-28

C-11 Characterization of Powders and Porous Materials

Instructors: Douglas M. Smith \& Joan E. Shields

Monday-Tuesday, Nov. 28-29

C-13 Atom Probe Microanalysis: Principles and Application to Materials Problems

Instructors: George D.W. Smith \& Michael K. Miller

Friday, Dec. 2

C-14 Fundamentals and Applications of Scanning Tunneling Microscopy Instructor: Robert J. Hamers

Monday, Nov. 28

$\$ 325$
Title

Tuition

C-16 Scanning Electron Microscopy and X-Ray Microanalysis Instructors: David C. Joy \& Dale E. Newbury

Tuesday, Nov. 29.

PREPARATION AND FABRICATION OF MATERIALS

P-01 Liquid Phase Epitaxy

Instructor: L. Ralph Dawson

Tuesday, Nov. 29

P-02 Molecular Beam Epitaxy

Instructor: Gary W. Wicks

Wednesday-Thursday, Nov. 30-Dec. 1

P-03 Vapor Phase Epitaxy

Instructors: Herbert M. Cox \& P. Dan Dapkus

Friday-Saturday, Dec. 2-3

P-05 Plasma Enhanced Chemical Vapor Deposition of Thin Films for Microelectronics

Instructors: Rafael Reif

Friday, Dec. 2

P-06 Ion Implantation, Diffusion, Defects, and Rapid Thermal Processing Instructors: Thomas E. Seidel, Steven C. Shatas \& Dennis M. Maher

Friday-Saturday, Dec. 2-3

$\$ 485$

P-12 Photon-Controlled Processing for Microelectronics

Instructor: Richard M. Osgood, Jr.

Monday, Nov. 28

P-14 Film Formation, Adhesion, Surface Preparation, and

Characterization of Thin Film Structures

Instructor: Donald M. Mattox

Friday-Saturday, Dec. 2-3.

P-15 Ohmic Contacts to Compound Semiconductors

Instructor: Peter A. Barnes

Monday, Nov. 28

F-01 Film and Coating Deposition Techniques

Instructor: Donald M. Mattox

Wednesday, Nov. 30

F-02 Plasma Etching for Microelectronic Fabrication

Instructor: G. Kenneth Herb

Tuesday, Nov. 29.

F-03 Ion Beam Processes for Materials Modification

Instructor: James K. Hirvonen

Friday, Dec. 2

PROCESSING/DIAGNOSTIC TECHNIQUES

T-05 Vacuum and Plasma Technology for Materials Processing

Instructor: Donald M. Mattox

Sunday-Monday, Nov. 27-28

T-06 Optical and Laser Diagnostics for Semiconductor Processing Instructor: Steven R. J. Brueck

Friday, Dec. 2

TO REGISTER: Call MRS at (412) $367-3003$ and ask for the Short Course Office. Ask about multiple course discounts, special tuition discounts, and a discount for MRS Fall Meeting registration. 